\title{
Janez Steble
}

University of Ljubljana

Faculty of Arts, English Department

Slovenia

\section{New Wave Science Fiction and the Exhaustion of the Utopian/Dystopian Dialectic}

\section{Summary}

The paper explores the development of the utopian and dystopian literature in the experimental and prolific period of New Wave science fiction. The genre literature of the period chiefly expressed the dissolutions of the universe, society, and identity through its formal literary devices and subject-matter, thus making it easy to arrive at the conclusion that the many SF works of J. G. Ballard's post-apocalyptic narratives, for example, exhausted and bankrupted the utopian/dystopian dialectic. However, the article provides textual evidence from one of the most prominent authors of the New Wave and the theoretical basis to suggest the contrary, namely that the categories of utopia and dystopia had by that time reached a level of transformation unprecedented in the history of the genre. Furthermore, the paper explores the inherent qualities science fiction shares with utopian literature, and suggests that the dialogism of the science fiction novel, especially that of the New Wave, has brought about the revival of utopia and rediscovered its potential.

Key words: The New Wave, critical utopia, postmodernism, entropy, heterotopia, transvaluation

\section{Novi val v znanstveni fantastiki in izčrpanost utopične/ distopične dialektike}

\section{Povzetek}

Članek raziskuje razvoj utopične in distopične literature v eksperimentalnem in plodnem obdobju Novega vala v znanstveni fantastiki. Žanrska literatura tega obdobja je izrazito poudarjala razkroj realnosti, družbe in identitete preko formalnih literarnih sredstev in čiste vsebine, kar nas lahko brez težav privede do zaključka, da mnoga ZF dela, npr. J. G. Ballardove post-apokaliptične pripovedi, predstavljajo iztrošenje in propad utopične/distopične dialektike. $\mathrm{V}$ članku pa so predstavljeni teksti pomembnih avtorjev Novega vala in teoretične osnove, ki predlagajo nasprotno misel, namreč, da so kategorije utopije in distopije do takratnega obdobja dosegle stopnjo preobrazbe, neprecedenčno v zgodovini žanra. Nadalje, prispevek odkriva inherentne lastnosti, ki jih znanstvena fantastika deli z utopično literaturo in nakazuje, da je dialogizem znanstvenofantastičnega romana, še posebej iz obdobja Novega vala, prinesel preporod utopije in ponovno odkril njen potencial.

Ključne besede: Novival, kritična utopija, postmodernizem, entropija, heterotopija, prevrednotenje 


\section{New Wave Science Fiction and the Exhaustion of the Utopian/Dystopian Dialectic}

\section{Introduction}

During the 1960s and 1970s occurred the "explosive upward mobility of previous depreciated cultural forms" (Pfeil 1990, 83), one of them being the paraliterature of science fiction. The genre underwent substantial changes, both in form and content, to "release writers and readers from the preconceptions of the pulp magazine idiom" (Greenland 1983, 167) and to further explore the core issues of contemporary society. What is termed as the New Wave science fiction is precisely the response to not only the then-relevant issues of psychology and sexuality, but most importantly to "mainstream" literary movements of the early 20th-century and the postwar period. In the span of a few decades, many genre authors ${ }^{1}$ used the literary forms and devices of modernism and postmodernism, embellishing their stories with an unprecedented degree of aesthetics. All of a sudden, it seemed that too many science fiction authors were preoccupied with how the story was written at the expense of subject matter. Familiar tropes of the genre, such as robots, aliens, outer space, high technology, became irrelevant; utopian longing, dystopian pessimism and the clashes between them were apparently replaced by the obsessive pursuit of the formal experiments common to James Joyce and William Burroughs. Owing to that, we can easily arrive at superficial conclusions that "... the very efflorescence of a highly literary science fiction in the 1960s was itself paradoxically the sign of a certain exhaustion of content, of the bankruptcy of the utopian/dystopian dialectic on which virtually all serious SF was based for the first hundred years of its existence ..." (Pfeil 1990, 92) or that "the science fiction of the New Wave allegorized the exhaustion of the 'real' - as represented by the dichotomous terms of redemption or damnation - through a baroque and over-elaborate writing that emphasized a pure materiality" (Bukatman 2005, 138).

To a certain extent, the argument has its merits; however, I wish to present the New Wave as the continuation of the utopian/dystopian dialectic by other means and emphasize the importance of this dialectic for the genre as a whole. The autotelic expressions of the period need not lead us to a literary impasse of baroque and decadence, but can show us "the new centrality of dilemmas of perception and representation as such" (Jameson 2007, 93). Of all the dilemmas the New Wave dealt with, I deem the issue of utopia and dystopia important in the future development of the genre.

\section{Romances of Entropy}

In A Canticle for Leibowitz (published 1960) we are presented with the cyclical history of death and destruction, where technological advancement leads to one global nuclear catastrophe to

Officially, these were the authors collaborating with the British magazine New Worlds, e.g. Michael Moorcock, Brian W. Aldiss, J.G. Ballard, under the editorship of Michael Moorcock, and the American anthology Dangerous Visions, e.g. Harlan Ellison, Samuel R. Delany, Thomas M. Disch, put together by Harlan Ellison. Unofficially, however, the New Wave movement was more or less part of the zeitgeist of the 1960s and the late 1970s, involving authors of varied and even conflicting interests. 
another. ${ }^{2}$ One of the last survivors murmurs "Sic transit mundus" ("thus passes the world") before leaving Earth for outer space where the cycle of doom can supposedly be avoided. The novel stands at a threshold between the Golden Age ${ }^{3}$ science fiction and the New Wave, and it definitely leans more towards the latter in terms of subject matter. It can be viewed as a cruel indictment of the space age optimism and a precursor to New Wave stories of entropy. The post-war period of rocket science, Cold War conflicts, and governmental hegemony created a hotbed for literature dealing directly with dissolutions ${ }^{4}$ ranging from personal to global issues. The optimism of the 1950s quickly turned into its opposite, utopias went into a steady decline. "For by the 1960s, the utopian mapping and dystopian exorcism ... had long since run aground" (Pfeil 1990, 84). This suggests that the polarity between utopia, based on the works of Thomas More, William Morris, Edward Bellamy, and dystopia, associated with Yevgeny Zamyatin, Aldous Huxley, George Orwell, ceased to exist. Before proposing arguments to the contrary, it is important to see why such a conclusion can be persuasive and truthful.

The most influential and groundbreaking authors of the New Wave are undoubtedly Michael Moorcock, Brian Aldiss, and J. G. Ballard. When Moorcock took over the editorship of New Worlds in 1964, the magazine became a proving ground for experimental fiction, embracing varied authors from both inside and outside the genre. It served as an avant-garde forum for speculative fiction, ${ }^{5}$ emphasizing the very aspects of society the previous forms of science fiction repressed, for example, sexuality. The essential role these authors played was to transform the genre from within with the help of the literary world from outside, meaning to break down the barriers of the genre ghetto. This opening of the sluice-gates immediately resulted in different forms of narrative, themes, and literary influences. ${ }^{6}$ What is most peculiar for science fiction of this period is that the genre had finally caught up with the modernism of the early 20thcentury. But even more fascinating is the fact that, although the New Worlds authors had been using outmoded literary fashions of modernism in their narratives, these New Wave stories also acted as precursors to cyberpunk and postmodernism. Style and aesthetics became highly sought aspects $^{7}$ and variegated elements made for this prolific period of the genre; however, in terms of pure content, there are nevertheless common concerns and dissatisfactions underlying the majority of these works. And as soon as we venture into these territories, we find ourselves in bleak and ravaged worlds in which it is difficult to see any form of utopia.

The above-mentioned conclusions of the literary critic Fred Pfeil were directly oriented towards J. G. Ballard's fiction, particularly the novels The Drought, The Drowned World, The Crystal World,

The novel mostly uses medieval imagery to express the themes of recurrence and cyclical history: "Are we doomed to it, Lord, chained to the pendulum of our own mad clockwork, helpless to halt its swing?" (Miller, Jr. 2007, 267).

3 These were the decades of John W. Campbell's exacting editorship of the highly influential Astounding Science Fiction. The trio Arthur C. Clarke, Isaac Asimov and Robert Heinlein represent the apex of the period.

These are also characteristic of postmodernist narratives.

The term was widely used by authors at the time to dissociate themselves from the earlier forms of science fiction.

William Burroughs became the new Renaissance Man for the movement, and the New Worlds authors continually praised him: "I was an admirer of Burroughs's use of modern imagery and idiom, for his metaphorical use of SF ideas, for his ear for the language and ironies of the drug underworld and of the streets" (Moorcock 2004, xx).

Brian W. Aldiss designated the search for style as an obsession permeating the New Wave: "Style - it implies a degree of selfconsciousness which wasn't there before, an element of outrageous showmanship, defiance, detachment, and just a touch of narcissism. Style - it is the heart of science fiction controversy in the sixties ..." (Aldiss 1986, 286-7). 
The High-Rise, and Concrete Island. All of these stories are in one form or another concerned with the disintegrations of subjectivity, inter-subjectivity, and the objective environments; more specifically, Ballard's fiction represents the dying of the capitalist class, finding no genuine redemption in either the bourgeois notion of progress or the socialist idea of radical revolution. His characters usually follow a pattern which can only mean the death of subjectivity as we know it - not fighting against the destructive environment, but embracing it. In The Drowned World, we follow Kerans's "neuronic odyssey" towards the southern regions of the dying Earth where we can only expect his imminent demise; we observe the steady decline of the environment, interpersonal relationships, and Kerans's own psychology through his eyes alone; the style is highly modernist with a special twist of the New Wave, i.e. Kerans's subjectivity is becoming one with the landscape; ${ }^{8}$ we see the gradual fusion of the outer environment and the inner landscape of the character's psyche, and when the fusion is complete, the novel must end, for then we have reached the unsayable. A great many of his stories deal with characters bent on self-destruction; what we are seemingly reading is a character's suicidal journey. And yet, we can actually find glimmers of hope, true happiness and even utopian longings in Ballard's entropic narratives. Before we peer into these glimmers, it is essential to underline and expose similar characteristic dissolutions in other authors as well.

What was said for Ballard, can be said not just for Moorcock and Aldiss but also for the majority of authors involved in the New Wave storytelling, and it is no wonder that at first glance we can judge the whole movement as spiralling towards the exhausted content. Moorcock is especially flamboyant in using the concept of entropy in his opus - the very character of Jerry Cornelius is a great metaphor for entropic identity in the modern world.' Science fiction tropes, such as time travel and parallel universes, become vehicles for the advanced decay of identity, Cornelius moves from antiquity to modern times, from life to death, only to seek a stable ontological centre, presented as an elusive goal. ${ }^{10}$ In the third Cornelius Chronicles novel, aptly named The English Assassin: A Romance of Entropy, the postmodern sense of precarious existence is succinctly summarised in the language of thermodynamics:

"If time could stand still," said Hira reflectively, "I suppose we should all be as good as dead. The whole business of entropy so accurately reflects the human condition. To remain alive one must burn fuel, use up heat, squander resources, and yet that very action contributes to the end of the universe - the heat death of everything! But to become still, to use the minimum of energy - that's pointless. It is to die, effectively. What a dreadful dilemma." (Moorcock 1977, 617)

The reverberation of the second law of thermodynamics is such a presence in the New Wave period that it essentially becomes a type of romance. Most notably, this is expressed in various end-of-the-world scenarios; the New Wave revelled in catastrophes and most of the time they

Ballard termed this process the "spinal landscape" whereby one's journey through the ravaged world is essentially a concrete metaphor for introspection.

9 "The entropic decay of the British empire mirrors the entropic decay of Jerry's attempts at constituting images of survival in dehumanized London as the sixties turn sourly downwards into the seventies" (Clute 1977, xii).

10 Jerry Cornelius's attempt to find stability in assuming a plethora of roles only backfires: "I thought l'd remain comparatively static while my surroundings were in a state of flux. But I appear to have been caught in the flux ..." (Moorcock 1977, 134). 
did not even bother with discerning the cause behind a global catastrophe. Even when Ballard "named" a catastrophe, i.e. The Drought, the focus was primarily upon the characters coping with the dying world, the acceptance of it and even finding happiness in it. The coming of the end of the universe becomes a grandiose festivity in Moorcock's series of novels The Dancers at the End of Time. The ravaged landscape thus becomes an aesthetic form - the end of the world for art's sake. However, that is merely one side of the coin.

End-of-the-world narratives were not merely autotelic experiments conducted on a set of exhausted themes and topics of science fiction literature. As mentioned earlier, modernism in Ballard's fiction becomes something different than in the realm of the "mainstream". The New Wave transformed the genre, both in form and content. Revelling in apocalyptic landscapes was for authors such as Ballard and Moorcock a unique approach at trying to solve classic epistemological and ontological dilemmas of science fiction. William Burroughs and James Joyce, as two of the main influences of the period, signify that authors of the genre used formal literary devices to express postmodern concerns, in effect respecting and continuing their legacy. Brian Aldiss's psychedelic pastoral Barefoot in the Head features a post-apocalyptic world caused by the spread of airborne psychedelics throughout western civilization. The author concretizes the dissolution of the western world via stream of consciousness and run-on sentences, the punctuation of poetry provides us with a commentary on the prosaic parts of the novel. And even though the portrayed world is a terrible place for existence, there is much concern about the happiness and the new way of living ${ }^{11}$ one can find in such a post-apocalyptic environment. The destruction of the "westciv" thus becomes an intermediary stage between "the pre-psychedelic" and "the post-psychedelic man". The formal devices borrowed from outside the genre helped Aldiss and a plethora of other authors of the period to find new meanings and values in the supposed imminent conflagration of our planet - destruction becomes a source of revival. Even the most morose and macabre fiction of Ballard's modernism includes not only a source of new formation of subjectivity, but also the transvaluations of utopia.

Positive aspects in Ballard's devastating and decadent tales are not at all difficult to find. If we take the previous example of The Drowned World, the protagonist's odyssey is peculiar precisely because the more he travels towards the death of his physical being, the more content he is. Consciously, he dreads the total change of the familiar environment, the reversion of our planet into a prehistoric environment, yet, unconsciously, ${ }^{12}$ that is exactly his ontological goal. At the very end, when he reaches his goal, he is compared to "a second Adam searching for the forgotten paradises of the reborn sun" (Ballard 2008, 175). It is difficult to accept the inevitable death of the character as a form of a happy ending, yet the author's approach to style and content would suggest exactly that, and perhaps we are not supposed to regard the physical death of Kerans as something tragic. In The High-Rise similar odysseys and unconscious strivings are present, yet this

11 The ravaged world of Barefoot quickly turns into an opportunity for a paradisiacal future: "Everyone's touched! Don't be taken in by appearances here. Believe me, the old world has gone, but its shell remains in place. One day soon, there will come a breath of wind, a new messiah, the shell will crumple, and the kids will run screaming, barefoot in the head, through lush new imaginary meadows ..." (Aldiss 1985, 39).

12 The Drowned World is a veritable fountain of Freudian language and imagery: "Just as psychoanalysis reconstructs the original traumatic situation in order to release the repressed material, so we are now being plunged back into the archeopsychic past, uncovering ancient taboos and drives that have been dormant for epochs" (Ballard 2008, 44). 
time the perversions affect thousands of denizens of the apartment complex which mirrors the modern society in all its contradictory nature. The eponymous building gradually turns from a rational society to a perverted Bakhtinian polyphony of carnivalesque and grotesque atmosphere. We may see the novel solely as the exploration of the exhaustion of the late-capitalist system, ${ }^{13}$ its intoxication with orgiastic display of death and decay, yet there is enough textual evidence to support a different point of view, a more favourable one, in which the literal crumbling of the high-rise represents the ascension of new subjectivity, a post-Freudian self:

Secure within the shell of the high-rise like passengers on board an automatically piloted airliner, they were free to behave in any way they wished, explore the darkest corners they could find. In many ways, the high-rise was a model of all that technology had done to make possible the expression of a truly "free" psychopathology. (Ballard 2011, 36)

We need not only dwell on the trio Moorcock, Aldiss, Ballard to understand the more positive sides of the science-fiction avant-garde. Thomas Disch, a renowned American New Wave writer, who knew a thing or two about dystopian projections, always found a way to integrate an aspect of life and beauty into the horrible vistas of the concrete horizon, ${ }^{14}$ he too was gravely aware of the encroaching entropy, yet offered glimpses of opposing forces. ${ }^{15}$ Further, Pamela Zoline's peculiar short story, published in New Worlds, about a housewife preoccupied with ontology and the meaning of entropy, is on the one hand a depressing descent into madness, but on the other hand, an ontological confirmation of the ubiquity of life. ${ }^{16}$ There is a profusion of similar examples throughout the works of Ballard and other New Wave authors in which the entropic state of (post)modern existence engenders brilliant science fiction tales of human revival and hope. The last part of the article will deal with the utopian and dystopian concerns of these apparent decadent storytellers, for now it is essential to see that even the most depressing and mean-spirited fiction of the New Wave offers a pleasurable aesthetic experience and a renewed interest in the contemporary world.

\section{The Utopian Nature of Science Fiction}

Science fiction is first and foremost, as the name implies, associated with scientific and technological aspects of modern society; secondly, with future-oriented fictional worlds,

13 The high-rise is, first and foremost, a microcosm of modern society: "What angered Wilder most of all about life in the apartment building was the way in which an apparently homogenous collection of high-income professional people had split into three distinct and hostile camps. The old social sub-divisions, based on power, capital and self-interest, had reasserted themselves here as anywhere else" (Ballard 2011, 53).

14 The dystopian novel 334 features niches of life and beauty among the endless concrete jungle: "There, not twenty feet below, was her story, the absolutely right thing: in a triangle formed by a feeder ramp to the highway and the building she was in and a newer building in the bony style of the 70s, was the loveliest vacant lot she'd ever seen, a perfect little garden of knee-high weeds. It was a symbol: of Life struggling up out of the wasteland of the modern world, of Hope..." (Disch 1974, 65).

15 In his Camp Concentration the rise of intelligence via syphilis-based injection makes the characters turn to alchemy and the occult for answers concerning their absurd existential position: "Science acquiesces, fatally, to the second law of thermodynamics - magic is free to be a conscientious objector. The fact is that I'm not interested in a universe in which I have to die" (Disch 1996, 75).

16 In her short story The Heat Death of the Universe the character Sarah Boyle finds through her obsessions with the entropic nature of the universe the logical existence of spaces opposed to disorganization: "In Gibbs' Universe order is least probable, chaos most probable ... there are local enclaves whose direction seems opposed to that of the Universe at large and in which there is a limited and temporary tendency for organization to increase. Life finds its home in some of these enclaves" (Zoline 2004, 142). 
extrapolated from the writers' and readers' present state of affairs; thirdly, with strange new worlds offering alternative modes of living. Even in these popular analyses there are implications of world-building, progress, and more perfect forms of social organizations. When an author posits some form of advanced technology to further the plot of their story, it is almost inevitable that this piece of technology will have ramifications on a social scale. It is up to the author to imply or explicitly state whether some device or invention turns out to be a benefit to society or a complete hazard. "[B]y imagining strange worlds we come to see our own conditions of life in a new and potentially revolutionary perspective" (Parrinder 2001, 4). The author's individual flight of fancy can thus quickly turn into a text of political, sociological and even critical implications. Science fiction is at its core a cognitive ${ }^{17}$ literature, a fictional account of the "presence and interaction of estrangement and cognition" (Suvin 1979, 7-8). When a new world, device or concept is introduced to estrange the reader's perceptions, they eventually find themselves familiarized with the estranging element, and the enchanting element becomes disenchanted.

"SF's domain is the possible. This is not a question of whether a fictive world is in reality impossible, actual, or possible, but rather, how the text implicitly asks the readers to respond to its invented reality as well as the state of science and technology when and where the work was composed" (Franklin 2009, 23). In the literary criticism of science fiction the category of reader is becoming more and more important, concepts of "cognition", "estrangement", "plausibility" abhor a reader's vacuum. Alternative worlds may start as an innocent introduction of a novum, ${ }^{18}$ but a text such as Le Guin's The Dispossessed which implements a novum in the form of an anarcho-communist society can rapidly transform into a didactic, critical, and revolutionary reading. The novel is essentially asking the reader to imagine a society, alternative to a capitalist one, and science fiction is one of the most effective literature and medium for engaging critical thinking. This is where we encounter the importance of the genre and its affinities with utopia.

Darko Suvin, as one of the first academic critics of the SF genre, designated utopia as a sociopolitical sub-genre of SF (Suvin 1979, 61), with utopia being an intrinsic part of the genre and also its predecessor (Suvin 1988, 42). Thomas More's inaugural work is indubitably connected with a plethora of stories in the fruitful periods of science fiction history, and that includes the bleak and pessimistic conclusions of the 20th-century dystopias. Indeed, a complex connection exists between More's Renaissance strivings of the nascent bourgeois class and the transvaluations of the New Wave SF utopian/dystopian writings. Starting from the book Utopia itself, the distinguishing features of this (sub-)genre immediately present themselves, namely the dissatisfactions of the current social system and finding the source of its evils, ${ }^{19}$ not just the panoramic view of the utopian society the author/narrator presents to

"... cognition - a central and informing concern for conceiving and discussing radically new views and understandings of human relationships and potentialities ..." (Suvin 1988, 30).

18 Suvin's term for scientifically plausible innovations in science fiction narratives.

19 Both features are strongly expressed in the first part of Utopia, mainly focused on presenting the wrongs of the author's society: "Though to speak plainly my real sentiments, I must freely own, that as long as there is any property, and while money is the standard of all other things, I cannot think that a nation can be governed either justly or happily; not justly, because the best things will fall to the share of the worst men; nor happily, because all things will be divided among a few (and even these are not in all respects happy), the rest being left to be absolutely miserable" (More 1997, 24). Furthermore: "For if you suffer your people to be ill educated, and their manners to be corrupted from their infancy, and then punish them for those crimes to which their first education disposed them, 
the readers in a monologic mode of discourse. ${ }^{20}$ It is myopic to reduce the concept of utopia to a form of escapism or an ideal society that cannot exist, we need only resort to an attentive reading of More to see that it is actually "an heuristic or educational device for perfectibility, an epistemological model and not an ontologically real country" (Suvin 1988, 42). Both utopia and science fiction are estranging genres, yet at the level of pre-science-fiction literary utopia we are given a relatively strong estrangement and a relatively weak cognition (Freedman 2000, 73), as More's formation of the island of Utopia and Swift's exotic lands, for example, attest. Come the New Wave SF period, the cognition in, e.g., John Brunner's dystopian cityscapes or Le Guin's self-critical utopias, is substantially strengthened, continuing More's imperative to imagine radical alternatives by other means.

"The traditional utopia takes the human condition as given, and hopes to make the human fit into utopia by legislation and education; the modern form of utopia regards a more perfect society to be the result of evolution and technology" (James 2008, 227). The judgment that the utopian/dystopian dialectic had ended by the middle of the 20th-century would only be entirely true if the technological developments, dissatisfactions and conflicts of the real world had ceased to exist. The findings of modern natural and social sciences, coupled with the post-war existentialist conundrums, modernized, refined and transformed the imagination for alternatives, and the aesthetic stage of the 1960s SF, including the most efflorescent and stylistic works revolving around the New Worlds experiments, contributed to the growth of the imagination. At the end of the 19th-century, News from Nowhere and Looking Backward represented the culmination of pre-science fiction utopian literature, and as soon as the October revolution degraded into a Stalinist oppressive regime, coupled with the rise of fascist ideology, it became a trend to turn to dystopian discourse, beginning with Zamyatin's We and culminating in Orwell's 1984. The idea that by the 1960s the visions of a better or worse world had subsided or even disappeared entirely from the literature of science fiction is all the more absurd due to the fact that it was in the 1960s and 1970s that a whole set of critical utopias ${ }^{21}$ came to the fore - Le Guin's The Dispossessed, Delany's Trouble on Triton, Piercy's Woman on the Edge of Time, Joanna Russ's The Female Man, to name a few. It should be noted that three of these authors were featured in Dangerous Visions, ${ }^{22}$ which represented a focal point for the American New Wave SF, therefore the utopian/dystopian dialectic not only did not cease to exist, it entered a new phase of development. However, before we explore the nature of these unprecedented developments, we should seek more reasons why science fiction is inherently imbued with the utopian/dystopian polarity.

Utopia is a literary genre or verbal construction whose necessary and sufficient conditions are the presence of a particular quasi-human community where socio-political institutions, what else is to be concluded from this, but that you first make thieves and then punish them?" (Ibid., 11)

20 One of the most important additions to the utopian discourse in the realm of SF is exactly in expanding the panorama of utopia via novelistic dialogic works of literature. Even News from Nowhere (1890), affiliated with the Marxist scientific analysis of society, fell victim to monologism: "Morris's text explicitly celebrates communist collectivity, but does so in a monologic, pre-novelistic form that depends heavily on individualist ideology" (Freedman 2001, 92).

21 More on this term in the next section of the article. According to Fredric Jameson, these works are the "rediscovery of SF's utopian vocation" (Jameson 2007, 289).

22 These works are Delany's "Aye, and Gomorrah...", Le Guin's The Word for World is Forest, and Russ's "When it Changed". 
norms and individual relationships are organized on a more perfect principle than in the author's community, this construction being based on estrangement arising out of an alternative historical hypothesis. (Suvin 1988, 35)

Instead of the abstract formulation in his general definition of the genre, "the presence and interaction of estrangement and cognition," here we find a socio-political specificity aimed at concretizing the vocation of cognition and estrangement in a manner befitting the discourse of the social sciences. The definition, if taken seriously, should put to rest various objections to utopian literature, namely its alleged social engineering of a faultless community; "the more perfect principle" relates to the spatio-temporal distance between the reader and the author, meaning that Plato's or More's conceptions of the locus of utopia may be another man's secular hell. More's fictional island is nevertheless based on a more perfect principle than his own empirical England. The narrative is indeed static, closed and monologic, yet any such fictional creation is based on the dynamic social forces, present from the times of Plato to the revival of the critical dystopias of the 1980s, such as Margaret Atwood's The Handmaid's Tale. Even though science fiction follows more closely the Bakhtinian concept of polyphony ${ }^{23}$ than the static panoramas of early utopias, they both have an affinity for objective social awareness and organisation. ${ }^{24}$ According to Suvin, utopia, especially More's work, is very familiar to and often equated with the mode and genre of satire; however, the fictional artefact of Utopia "explicates what satire implicates, and vice versa" (Suvin 1979, 54). Satire in general explains human nature, its merits and demerits, yet implies the social structure of a more perfect community, and therefore the reduction of Utopia to satire is insufficient for the scope of literary criticism. There are many more modes and genres connected with the history of utopia, such as folk tales, myths, cockaynes, etc., but for our purposes the homology, posited by Suvin, between science fiction and utopia should suffice to see their combined and uneven development from the 16th-century to (post)modern times.

Lastly, the interrelation between utopia and science fiction lies in the Blochian concept ${ }^{25}$ of utopian impulse, which is greatly emphasized by Marxist literary critics, e.g., Darko Suvin, Fredric Jameson, and Carl Freedman. Bloch did not speak directly of science fiction or the genre of utopia per se; he has reinterpreted utopia in general "as being any overstepping of the boundaries given to man, hence a quality inherent in all creative thought and action" (Suvin 1979, 39). It is essentially a characteristic of human nature, an omnipresent impulse. The concept is much easier to connect to science fiction in general than the afore-mentioned rigorous formulations of Suvin. One could say that it is actually too abstract and de-politicized to be of any use, yet thinkers like Bloch saw that the only solution in reviving utopia amidst the disappointments of unsuccessful revolutions and oppressive political actions was to make it part of critical thinking ${ }^{26}$ and artistic endeavours. As Jameson notes, there are "two distinct lines of descendency from More's inaugural text: the one intent on the realization of the Utopian program, the other an obscure yet omnipresent Utopian impulse finding its way to the surface in a variety of covert

23 Le Guin's The Dispossessed is a great example of that, since the utopia of the arid planet Anarres is constantly the subject of selfcriticism and is posited against the conflicting nation-states of Urras.

24 Utopian literature in general deals with social organisations: "There are no unorganized utopias" (Suvin 1979, 50).

25 The primary source of the concept comes from Ernst Bloch's Das Prinzip Hoffnung (3 vols.: 1938-1947).

26 Similarly, Marxism in late-capitalism has been more successful in integrating itself into literary criticism than into parliamentary politics 
expressions and practices" (Jameson 2007, 3). It is not surprising to see Nazism in the "second line"; the concept of utopia has never been without its abuses and dangers, ${ }^{27}$ since what has been de-politicized can become fully political again. This is indeed a paradox, and not the only one.

According to Bloch, utopia is always on the horizon, never a reachable and graspable topos, yet we have since time immemorial always felt at home with the concept; it is our final destination, an un-alienated space, yet without ontic reality. In the end, this unreachable goal is our purest motive for changing the status quo, striving to go beyond the confines of one's society. This paradoxical twist of immanence and transcendence constitutes utopia, and what immediately concerns us here is that Bloch's utopian hermeneutics directly provide the genre with a sense of critique. The New Wave SF period, instead of exhausting the utopian content, revived it with an onslaught of critical utopias and dystopias, offering marginalized layers of society not just economic and political answers, but genuine utopian vistas of Blochian proportions.

\section{Transformations and Transvaluations}

The explosive, turbulent and prolific decades of the 1960s and 1970s saw the rise of a whole generation of genre authors trying - and most of the time, succeeding - in breaking down the barriers of the genre ghetto and, in effect, improving the overall status and reception of science fiction. The inherent attractions between science fiction and utopia, coupled with the bold enterprise of the New Wave aesthetics and conceptions, resulted in the intensification of the utopian/dystopian dialectic. The authors, dealing with new epistemological and ontological issues "transformed [in the sense of aufheben] the traditional utopia in the triple sense of that term: that is, they ... negated ... [and] preserved ... [as well as] transformed it" (Somay 1984, 25). This sublation engendered creativeness from both the utopian and the dystopian camp; it is, in fact, much easier and more correct to simply call the works of the period critical utopias and dystopias. The main difference between these transformed sub-genres and the past forms of the utopian and dystopian literature is that the former include within themselves a dialectical opposition between the utopian and dystopian strivings - a tour de force of Blochian pulsation and Bakhtinian heteroglossia. As opposed to the ultimate pessimism or optimism in 1984 or News from Nowhere, respectively, the New Wave proposed a dialogue between the two.

The dialogue can best be seen in two of the most critically acclaimed works of science fiction of the 20th-century concerning the topic, namely Le Guin's The Dispossessed and Delany's Trouble on Triton. ${ }^{28}$ The latter is a direct response to the former, which is already visible in Delany's sly subtitle. Both works use science fiction tropes and the tools of social sciences to deal directly with the issues on utopia, eutopia, ${ }^{29}$ dystopia, and even heterotopia. In Le Guin's work we follow the journey of the physicist Shevek from his home planet to the neighbouring moon of Urras and back again. ${ }^{30}$ The whole novel can be seen as following the dialectical law of negation of the negation, whereby the utopia of Anarres is firstly negated by one of the capitalist societies of

${ }_{27}$ If logical and consistent, utopia is essentially totalizing, but not intrinsically leaned towards totalitarianism. The danger, however, is always present (Levitas and Sargisson 2003, 18) .

28 Full names of the novels are: The Dispossessed: An Ambiguous Utopia, Trouble on Triton: An Ambiguous Heterotopia.

29 A good place (eu-topos), as opposed to the no-place of u-topos.

30 He is essentially materializing the Taoist saying of Odo, the founder of the anarcho-communism of Annares: "true journey is return". 
Urras, and the latter negated by the new realizations and experiences of Shevek, thus confirming the utopia of his home planet, but on a more profound level. The subtitle "ambiguous utopia" refers, of course, to the spartan conditions of Shevek's birthplace. Le Guin was certainly not naive when constructing this fictional topos; she knew the historical lessons of capitalism, fascism, and Stalinism, ${ }^{31}$ and opted for a combination between anarchism and communism ${ }^{32}$ to be her model society, against which we can see the merits and demerits of both our own empirical sociopolitical system and that of the novel. The society of Anarres is flawed: the planet is almost arid, the ecological conditions alone cannot yield a community of superabundance, ${ }^{33}$ the technology is crude, the communication between Anarres and Urras and other regions of the desert planet is limited, and, worst of all, there is a hidden authority pervading every pore of Anarresti existence; ${ }^{34}$ in other words, it is a far cry from what is considered utopia proper.

Therein lies the critical capacity of the novel. Shevek, as the protagonist, realizes the flawed nature of materializing Odonian principles on a barren planet, but nevertheless strives to better the community which bore and raised him. The first chapter starts with Shevek fleeing from Anarres, which is literally enclosed by a wall ${ }^{35}$ - the enclosed utopian space is broken through, and thus the first step towards the genuine utopian horizon ${ }^{36}$ is taken. What Shevek brings from his ordeal on Urras is the hope for the future of Anarres and "the self-critique of anarchism" (Freedman 2000,122 ). The novel is a critical utopia because of its auto-referentiality, ${ }^{37}$ its self-awareness of the genuine utopian vocation; the society of Anarres becomes an open-ended utopia. Samuel Delany, on the other hand, effaces the utopian horizon entirely (Somay 1984, 33). Trouble on Triton is focused on the inviolability of subjectivity and the possibility of heterotopian spaces existing side by side in a non-hegemonic totality. The journey of the protagonist Bron Helstrom is essentially the movement from one community to the next, from Triton to Earth and back again, following the similar path of Shevek, yet this time Bron's spaces of Triton, Mars and Earth offer no places presenting themselves as utopian; they are just spaces with a wide variety of choices and life-styles. Delany does not hide the fact that the concept of heterotopia is borrowed from Michel Foucault, ${ }^{38}$ and the novel's unique space of "unlicensed sector" can be easily compared

31 However, she chose to equate it with Marxism.

32 To be precise, this is anarchist communism (anarcho-communism), whereby communist goals, i.e., abolition of private property and the institution of communal ownership, are achieved via direct democracy, rather than political parties/representatives.

33 A society of superabundance is one of the main goals of the socialist revolution; however: "The socialist project under conditions of economic underdevelopment must, in fine, be a decidedly ambiguous one" (Freedman 2000, 123).

34 Shevek and the few around him realize that the absence of an official government and authority on Anarres does not negate repression, but only confirms it on a different level: "Public opinion! That's the power structure he's part of, and knows how to use. The unadmitted, inadmissible government that rules the Odonian society by stifling the individual mind" (Le Guin 2004, 138).

35 The wall is a leitmotif of the novel, representing the limitations of the objective conditions of Anarres and Urras and the critical capacities of their peoples.

36 "The utopian horizon in The Dispossessed is a horizon in the true sense of the word: it is there and approachable; but ever extending upwards to a totality which is infinite, it can never be reached" (Somay 1984, 35).

37 We should take cognizance of the fact that auto-referentiality and self-reflexivity are one of the main literary techniques the New Wave adapted from the "mainstream" of modernism and postmodernism.

38 "Heterotopias are disturbing, probably because they make it impossible to name this and that, because they shatter or tangle common names, because they destroy 'syntax' in advance, and not only the syntax with which we construct sentences but also that less apparent syntax which causes words and things (next to and also opposite one another ) to 'hold together' ... heterotopias ... desiccate speech, stop words in their tracks, contest the very possibility of grammar at its source; they dissolve our myths and sterilize the lyricism of our sentences" (qtd. in Delany 1996, 292). 
to Foucault's "heterotopia of deviation." ${ }^{39}$ U-1 sectors provide relative freedom and safety in the form of a combination between lawlessness, criminality, and deviant communities, something unseen either on Mars or Earth.

The problem with Bron is that none of these spaces provide a happy and reasonable existence for him; he even undergoes a sex change to attempt to achieve that, yet finds no stability and meaning in either heterosexuality, homosexuality or transsexuality. The background of the novel revolves around the political tensions between Triton and Earth, leading to interstellar war. Triton fights to "to make the subjective reality of each of its citizens as politically inviolable as possible" (Delany 1996, 225-6); it should be a perfect place for Bron, considering he was born and raised in the stifling atmosphere of Mars, but it seems he only has the negative capacity for utopia, ${ }^{40}$ rather than Shevek's critical one. In the end, Delany presents us with a set of heterotopian spaces, some more favourable than others, and if Triton is utopia at all, ${ }^{41}$ it is not only ambiguous and transformed, but transvaluated. Delany in Trouble on Triton "couples science fiction with modernist poetics, exploiting science fiction's ontological motifs yet holding them in check by means of a modernist epistemological frame" (McHale 2003, 70). The same can be said of The Dispossessed and the New Wave period in general. While Le Guin gave us, through a "modernist epistemological frame," the critical capacity for utopia, Delany seems to have moved into yet another category, that of negative capacity. Bron is stuck somewhere between utopia and dystopia, in some heterotopian space ${ }^{42}$ where the difference between happiness and misery is blurred and unrecognizable, or simply given a different value. What if Delany's contribution to the utopian/dystopian dialectic brought us to another realm entirely? There is certainly no answer to that. If Le Guin wrote an open-ended utopia with a clear and positive horizon, Delany can be said to have written an open-ended heterotopia with an unrecognizable horizon. However, there is another author who tried to transvaluate the utopian strivings, one far more bizarre and extreme.

J. G. Ballard's flirtings with the apocalypse and entropy, starting with his debut The Drowned World (published 1962), immediately negated the optimism of the 1950s. In his whole opus both technocrats and tycoons are out of place in the surrealist landscapes of physical and psychological decay, the protagonists consistently proceed into their own demise. The afore-mentioned critic Fred Pfeil took Ballard as the main example of the New Wave exhaustion of "the real", especially the utopian/dystopian dialectic. So far, we have shown that the New Wave authors in general found the enclaves of happiness and meaningful existence in even the bleakest possible scenarios. And what of Ballard? Trouble on Triton demonstrates how the issue on utopias and dystopias can be further expanded by moving to different categories and values, i.e., heterotopia and negative

See "Of Other Spaces" (1967). Full text available here: <http://foucault.info/documents/heteroTopia/foucault.heteroTopia.en.html>

40 For Bron the meaning of a happy place is related to realizing one's personal preferences; he, however, can only dwell in personal dislikes and troubles: "Somewhere, in your sector or in mine, in this unit or in that one, there it is: pleasure, community, respect - all you have to do is know the kind, and how much of it ... But what happens to those of us who don't know? What happens to those of us who have problems and don't know why we have the problems we do? What happens to the ones of us in whom even the part that wants has lost, through atrophy, all connection with articulate reason. Decide what you like and go get it? Well, what about the ones of us who only know what we don't like?" (Delany 1996, 104).

41 There are certainly people of various interests and life-styles on Triton who have a more reasonable and happier existence than Bron.

42 Perhaps we can designate it as an ambiguous heterotopian space. 
capacity. In Ballard's case, it is essentially the same - the transvaluation occurs. ${ }^{43}$ In The Drowned World the entire planet is undergoing a regressive ecological and geographic transformation Earth is reliving its prehistoric era, reptilian life-forms and hot temperatures are on the rise. Simply put, human existence as we know it has no place in such a world. Ballard then proceeds to show that re-establishing enclaves of capitalism or fighting against the dying world is irrelevant - "the environmental change has rendered the values of the 20th-century urban civilization meaningless" (Firsching 1985, 302). The protagonist Kerans gradually realizes his dreams and visions are preparing him for a new reality. ${ }^{44}$ His southward odyssey, in the end, bestows upon him a solitary paradise, the identity of "a new Adam" at the expense of his old physical self. Other characters around him more or less experience the same odyssey, yet this is all achieved on a solitary level.

The High-Rise shows a similar path towards new values and selves, yet this time it involves the entire apartment complex. We should bear in mind that "many utopian visions are grounded in such members of the idealist family of world-views as Platonism, mysticism, orthodox religious piety, and modern and postmodern irrationalism" (Wagar 1991, 56). Indeed, in Ballard's fiction we should forego the rational Western view towards utopia; his is simply an irrationalist worldview (Firsching 1985, 302). New world order arising out of the prehistoric waters of The New World or the dissolutions of capitalist social roles is incomprehensible, Ballard has to resort to the language of surrealism and mysticism to convey messages of irrational utopianism. "Ballard's higher social order has no discernible political, economic, or social structure. It is not a kingdom of this world at all. Its laws are the laws of spirit, of psychic transcendence, wholly above and beyond ordinary waking reason" (Wagar 1991, 58). For him, it is all about transcending the limitations of the late-capitalist self. In the end, the utopian goal for Ballard is "the repossession of man of authentic and absolute being" (qtd. in Wagar 1991, 55), at one point named as "the forgotten paradises of the reborn sun" and at the other as "new Jerusalem", but never wholly comprehensible and totalizing à la More's Utopia.

\section{Conclusion}

The New Wave aesthetics proved to be more than a baroque addition for the genre. The movement was comprised of various authors with various interests, and it was inevitable that the ever-present enterprise of utopian and dystopian constructions would be touched upon. As it turns out, almost every single author, especially a great many contributing to New Worlds or Dangerous Visions, either directly or indirectly dealt seriously with the growth of the utopian/ dystopian dialectic, resulting in some of the most fascinating works of utopian science fiction of the 20th-century - works such as The Dispossessed and Trouble on Triton. The new form of science fiction was accompanied by the transformed and transvalued categories, e.g., Le Guin's critical utopia and Ballard's irrational one. The monologism of the pre-science fictional utopias was in this process discarded; in actuality, there was no genuine "exhaustion of the content", but merely

43 Furthermore, Ballard is even more proficient in the use of a modernist epistemological frame.

44 New reality begets new (unknown) categories: "Sometimes he wondered what zone of transit he himself was entering, sure that his own withdrawal was symptomatic not of a dormant schizophrenia, but of a careful preparation for a radically new environment, with its own internal landscape and logic, where old categories of thought would merely be an encumbrance" (Ballard 2008, 14). 
the sublation of the utopian concept. The New Wave romances of entropy, featured mostly in the apocalyptic fiction of the famous trio of the period - Moorcock, Aldiss, Ballard, upon detailed reading provide readers with pleasure, hope, and also utopian longings. Finally, the bizarre and extreme case of J. G. Ballard tells us that contrary to superficial readings of his surrealist postapocalyptic landscapes, the stories are actually endowed with the humanist value of finding authentic being amidst the ever-changing and decadent environments. His transvalued utopias are extremely different from the classic secular kingdoms of heaven, but there can be no doubt that the search for eu-topos is explicit.

\section{Bibliography}

Aldiss, B.W. 1985. Barefoot in the Head. London: Grafton Books.

--- , and D. Wingrove. 1986. Trillion Year Spree: The History of Science Fiction. London: Victor Gollancz.

Ballard, J.G. 2008. The Drowned World. London: Harper Perennial.

---. 2011. The High-Rise. London: Fourth Estate.

Bukatman, S. 2005. Terminal Identity: The Virtual Subject in Postmodern Science Fiction. Durham, North Carolina: Duke University Press.

Clute, J. 1977. The Repossession of Jerry Cornelius. In M. Moorcock, vii-xv. New York: Avon Books.

Delany, S.R. 1996. Trouble on Triton: An Ambiguous Heterotopia. Middletown: Wesleyan University Press.

Disch, T.M. 1974. 334. London: Sphere Books.

---. 1996. Camp Concentration. New York: Vintage Books.

Firsching, L.J. 1985. J. G. Ballard's Ambiguous Apocalypse (L'apocalypse ambiguë de J. G. Ballard). Translated and edited by R. M. P. Science Fiction Studies 12, no. 3 (November): 297-310.

Franklin, H.B. 2009. What is Science Fiction - And How it Grew. In Reading Science Fiction, ed. J. Gunn, M.S. Barr, and M. Candelaria, 23-33. New York: Palgrave Macmillan.

Freedman, C. 2000. Critical Theory and Science Fiction. Hanover and London: Wesleyan University Press.

---. 2001. Science Fiction and Utopia: A Historico-Philosophical Overview. In Learning from Other Worlds: Estrangement, Cognition, and the Utopian Politics of Science Fiction and Utopia, ed. P. Parrinder, 72-98. Durham: Duke University Press.

Greenland, C. 1983. The Entropy Exhibition: Michael Moorcock and the British New Wave in Science Fiction. London: Routledge \& Kegan Paul.

James, E. 2008. Utopias and Science Fiction. In The Cambridge Companion to Science Fiction, ed. E. James and F. Mendlesohn, 219-230. New York: Cambridge University Press.

Jameson, F. 2007. Archeologies of the Future: The Desire Called Utopia and Other Science Fictions. New York: Verso.

Le Guin, U. 2004. The Dispossessed. London: Gollancz.

Levitas, R., and L. Sargisson. 2003. Utopia in Dark Times: Optimism/Pessimism and Utopia/Dystopia. In Dark Horizons: Science Fiction and the Dystopian Imagination, ed. R. Baccolini and T. Moylan, 13-29. New York: Routledge.

Miller, Jr., W.M. 2007. A Canticle for Leibowitz. New York: Bantam Dell.

McHale, B. 2003. Postmodernist Fiction. London and New York: Routledge.

Moorcock, M., ed. 2004. New Worlds: An Anthology. New York: Thunder's Mouth Press.

---. 1977. The Cornelius Chronicles. New York: Avon Books. 
More, Sir Thomas. 1997. Utopia. New York: Dover Publications.

Parrinder, P. 2001. Introduction to Learning from Other Worlds: Estrangement, Cognition, and the Utopian Politics of Science Fiction and Utopia, ed. P. Parrinder, 1-18 Durham: Duke University Press.

Pfeil, F. 1990. Another Tale to Tell: Politics and Narrative in Postmodern Culture. New York: Verso.

Somay, B. 1984. Towards an Open-Ended Utopia (Vers une utopie ouverte). Translated and edited by R. M. P. Science Fiction Studies 11, no. 1 (March): 25-38.

Suvin, D. 1979. Metamorphoses of Science Fiction: On the Poetics and History of a Literary Genre. New Haven and London: Yale University Press.

---. 1988. Positions and Presuppositions of Science Fiction. Ohio: Kent State University Press.

Wagar, W.W. 1991. J. G. Ballard and the Transvaluation of Utopia (J. G. Ballard et la transvaluation de l'utopie). Science Fiction Studies 18, no. 1 (March): 53-70.

Zoline, P. 2004. The Heat Death of the Universe. In New Worlds: An Anthology, ed. M. Moorcock, 131-45. New York: Thunder's Mouth Press. 